\title{
HPV infections in head and neck cancers (HNSCC) - clinical course and efficiency of therapy
}

\section{Zakażenie HPV a przebieg kliniczny i skuteczność terapii w nowotworach głowy i szyi (HNSCC)}

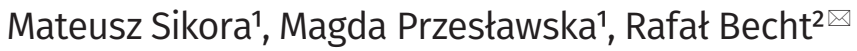 \\ 1 Pomorski Uniwersytet Medyczny w Szczecinie, Studenckie Koło Naukowe przy Oddziale Klinicznym Onkologii, Chemioterapii i Immunoterapii Nowotworów, \\ ul. Unii Lubelskiej 1, 71-252 Szczecin \\ Pomeranian Medical University in Szczecin, Student Scientific Circle by the Clinical Department of Oncology, Chemotherapy and Cancer Immunotherapy \\ 2 Pomorski Uniwersytet Medyczny w Szczecinie, Oddział Kliniczny Onkologii, Chemioterapii i Immunoterapii Nowotworów, \\ ul. Unii Lubelskiej 1, 71-252 Szczecin \\ Pomeranian Medical University in Szczecin, Clinical Department of Oncology, Chemotherapy and Cancer Immunotherapy \\ $\triangle$ rbecht@pum.edu.pl
}

\begin{abstract}
Head and neck cancers represent a heterogenous group of neoplasms. Among them, the most frequently occurring is squamous cell carcinoma. Risk factors that can contribute to the development of head and neck cancers are smoking, high proof alcohol abuse and human papilloma virus (HPV) infection. Head and neck cancers may be divided into HPV positive and HPV negative. This division shows the different landscape of carcinogenesis, median age of onset, etiopathogenesis, clinical course and treatment efficiency. Head and neck squamous cell carcinoma (HNSCC), especially HPV positive, belongs to highly immunogenic cancers. Its development relates to HPV infection and host immune response, especially with T regulatory lymphocytes response. Programmed cell death protein-1 (PD-1), which shows immunosuppressive effect on host's immune system, takes part
\end{abstract}

in cancerogenesis. That favours carcinogenesis. The development of immuno-oncology and better understanding of HNSCC pathogenesis has contributed to developments in immunotherapy, a method of care which is used preferably in the treatment of advanced, refractory or relapsed cancers that did not respond to standard-of care cancer treatments - in the case of HNSCC it is surgical resection with possible radiochemotherapy or chemotherapy. The idea of immunotherapy is to remove tumor immunosuppressive effect and to boost host immune response to eliminate neoplasm.

This article shows a review of current knowledge and new methods of therapy concerned with HNSCC treatment, especially HPV positive HNSCC.

Keywords: head and neck cancer; human papilloma virus; immunotherapy; T lymphocytes; immunity.

\begin{abstract}
ABSTRAKT
Nowotwory głowy i szyi stanowią heterogenna grupę chorób rozrostowych, spośród których najczęściej występuje rak płaskonabłonkowy. Czynnikami mogącymi predysponować do rozwoju nowotworów głowy i szyi są: palenie papierosów, spożywanie alkoholu wysokoprocentowego, a także zakażenie ludzkim wirusem brodawczaka (human papilloma virus - HPV). Z tego powodu nowotwory głowy i szyi często dzieli się na HPV pozytywne i HPV negatywne. W zależności od statusu HPV obserwuje się różnice w medianie wieku zachorowania oraz w samym przebiegu klinicznym choroby i w odpowiedzi na stosowane leczenie. Rak płaskonabłonkowy głowy i szyi (head and neck squamous cell carcinoma - HNSCC), szczególnie HPV dodatni, należy do nowotworów, które są ściśle związane z układem immunologicznym. Jego rozwój związany jest z reakcjami pomiędzy wirusem HPV a limfocytami $T$ regulatorowymi gospodarza. $W$ karcynogenezie główną rolę odgrywa m.in. receptor programowanej śmierci-1
\end{abstract}

(programmed cell death protein-1 - PD-1), którego pobudzenie wykazuje immunosupresyjne działanie na układ immunologiczny gospodarza, co sprzyja rozwojowi nowotworu. Rozwój immunoonkologii oraz poznanie i zrozumienie patogenezy nowotworów głowy i szyi przyczyniły się do opracowania metod terapii wykorzystujących składowe układu immunologicznego. Leczenie to stosowane jest głównie w zaawansowanych i nawrotowych nowotworach, które nie odpowiadają na standardowe procedury lecznicze. Immunoterapia ma na celu zniesienie immunosupresyjnego działania guza i zwiększenie aktywności limfocytów T gospodarza do zwalczania nowotworu.

W pracy przedstawiono przegląd obecnej wiedzy dotyczącej przebiegu klinicznego i odpowiedzi na leczenie w nowotworach głowy i szyi, które związane są z zakażeniem wirusem HPV. Słowa kluczowe: nowotwory głowy i szyi; ludzki wirus brodawczaka; immunoterapia; limfocyty T; odporność.

\section{INTRODUCTION}

Head and neck cancers are a heterogenous group of tumors with an origin in the oral cavity, nasal cavity, paranasal sinuses, pharynx and larynx. Squamous cell carcinoma is a histological type appearing most frequently but other cancer variants as well as sarcomas and lymphomas can be present in this region. Head and neck squamous cell carcinoma (HNSCC) is characterized with a poor prognosis. Recurrent and metastatic disease is usually incurable, so newer more effective methods of treatment are being sought [1]. These diseases belong to neoplasms highly associated with the immune system. Patients suffering 
from HNSCC have lower lymphocyte numbers in peripheral blood than healthy people, spontaneous apoptosis of cytotoxic T lymphocytes can be observed, and natural killer (NK) cells show limited activity in presenting antigen processes $[2,3,4]$. Tumor immunosuppressive effect and the amount of tumor infiltrating lymphocytes became a base for introducing immunotherapy for this malignancy [5]. This type of treatment is more effective in some groups of patients - greater complete response rate (CRR) and overall survival (OS) can be observed with less intensified adverse events in comparison with standard therapy [6, 7]. It is crucial for patients who have developed HNSCC with pathogenesis associated with human papilloma virus (HPV) infection - immunotherapy has the best efficacy in this group of patients.

\section{EPIDEMIOLOGY}

Head and neck squamous cell carcinoma is the sixth most frequently diagnosed malignancy in the world and over half a million of new cases are diagnosed every year [8]. Most tumors are localized in the oral cavity, nasopharynx, oropharynx and hypopharynx. Considering all the places of origin and clinical advancement stages, HNSCC is characterized with a $65.9 \%$ 5-year OS and 2.5 year median survival when treated [9]. Recently, a trend in reducing HNSCC connected with smoking and alcohol and increasing population with HNSCC connected with HPV infection is observed [10]. Human papilloma virus positive HNSCC in the global population is noted in $25-80 \%$ of cases [11]. These patients are younger; a typical HPV positive HNSCC patient is a 40-59 year old male of Caucasian origin, not smoking, with high socioeconomic status, having many sexual partners $[12,13]$. Patients with this type of cancer do not abuse alcohol. Most frequently anatomical localization of HPV positive HNSCC is oropharynx, where $90 \%$ of cases are infected with HPV-16 [11, 13]. The International Agency for Research on Cancer classified HPV-16 as a Group 1 carcinogen (proven cancerogenic effect) of the oropharynx and oral cavity [14]. Beside HPV-16, HPV-18, 33 and 52 types are strongly associated with HNSCC, especially in the hypopharynx [15]. Human papilloma virus positive oral HNSCC patients show greater disease-free survival (DFS) and OS rate in comparison with HPV negative oral HNSCC (75\% vs. $14 \%$ and 79 vs. 19\% respectively) [16]. A difference in response to chemotherapy and chemoradiotherapy is observed depending on the HPV status in HNSCC of oropharynx. Chemotherapy response rates (RR) are higher in HPV positive patients $-82 \%$ vs. $55 \%$ in HPV negative patients. A similar phenomenon is observed when receiving chemoradiotherapy $-84 \%$ vs. $57 \%$ respectively [17].

\section{ETIOPATHOGENESIS}

Human papilloma virus is a DNA-virus belonging to the Papillomaviridae family and showing squamous epithelium tropism. By 2015, 202 of HPV types had been isolated [18]. They can be distinguished into 2 groups depending on malignancy potential. High-risk group are: HPV-16, 18, 31, 33, 35, 39, 45, 51, 52, 56, 58, 59, 68. Low-risk group are: HPV-26, 30, 34, 53, 66, 67, 69, 70, $73,82,85$ [11]. Low-risk types contribute to benign condylomata acuminata lesion development. High-risk types favour intraepithelial neoplasia which can develop into cancer. Among all cancers, $5 \%$ are tumors with high-risk type HPV infection.

In chronic HPV infection, E2 viral protein controls expression of 2 viral oncoproteins - E6 and E7. They are inhibitors of cancerogenesis suppressors - pRb and p53. In precancer lesions and cancers, the function of E2 is impaired which results in a greater E6 and E7 expression. Inhibiting pRb and p53 expression leads to destabilization of the cell cycle where proliferation, apoptosis and genetic stability is controlled, so epithelial lesions can occur [18].

\section{IMMUNOTHERAPY}

In recent years a lot of clinical studies focussed on monoclonal antibody therapy, so called immune checkpoint inhibitors. These antibodies are anti-programmed cell death protein-1 (PD-1) and anti-cytotoxic T-cell antigen 4 (CTLA-4). The first drug which showed an immune checkpoint inhibitor effect was registered by the Food and Drug Administration (FDA) as cetuximab. It is a monoclonal antibody which binds to the extracellular domain of epithelial growth factor receptor (EGFR) and disables its activation. Head and neck squamous cell carcinoma is characterized with EGFR overexpression and its cancerogenesis is stimulated by amphiregulin and tumor necrosis factor $\alpha$ which stimulate EGFR [5]. Despite EGFR overexpression being rather typical in HPV negative HNSCC, in HPV positive HNSCC EGFR pathologic signalling is observed due to viral oncoproteins effect [19]. Cetuximab treatment is indicated in metastatic/ recurrent HNSCC when failure after platinum-based therapy is observed [20]. Currently, RTOG 1016 study is performed where authors are comparing cetuximab vs. cisplatinum + radiotherapy in HPV-related HNSCC - results are in progress [21].

Pembrolizumab is an anti-PD-1 agent which binds to PD- 1 and reduces its activity. Programmed cell death protein-1 is a protein which takes part in reducing T lymphocyte activity and this mechanism is secure from immune system auto-aggression. In cancerogenesis PD-1 action leads to a repeal of immunological surveillance. Head and neck squamous cell carcinoma cells can use PD- 1 and CTLA- 4 to progress. The KEYNOTE-012 study considered HNSCC patients HPV status. This study explored pembrolizumab safety and efficacy in metastatic/recurrent disease. The $28 \mathrm{HPV}$ positive and $104 \mathrm{HPV}$ negative patients were recruited. Overall response rate (ORR) was $32 \%$ in HPV positive patients and $14 \%$ in HPV negative patients. The 6-month progression free survival (PFS) was $37 \%$ in HPV positive group and $20 \%$ in HPV negative group, 6-month OS noted as 70\% in patients infected with HPV and $56 \%$ in patients whose cancer was not connected with HPV infection [22].

Nivolumab is an anti-PD-1 antibody. Based on the results of the CheckMate 141 study, in which HNSCC treatment with 
nivolumab was compared with cetuximab/methotrexate/ docetaxel chemotherapy, the FDA approved nivolumab in recurrent/metastatic HNSCC disease in the group of patients who had previously received platinum-based chemotherapy. The study results suggest that patients treated with nivolumab have better median OS outcome (7.5 months) than patients treated with cetuximab/methotrexate/docetaxel (5.1 months). Nevertheless, the authors did not consider patient HPV status and its influence on the studied results [23]. In another study, 29 patients not-pretreated with HNSCC of the oropharynx, hypopharynx or larynx received $240 \mathrm{mg}$ of nivolumab twice before surgical resection. The study population included $12 \mathrm{HPV}$ positive and $17 \mathrm{HPV}$ negative patients. Two HPV positive patients experienced treatment related adverse events graded 3-4: higher lipase concentration and glossodynia. Adverse effect was observed also in 2 HPV negative patients: higher lipase concentration. The treatment related adverse effects did not delay surgery. After the operation, tumor reduction was assessed in $11 / 23$ patients: $5 / 10$ patients from the HPV positive group and 6/13 from the HPV negative group [24]. Currently, the Check Mate 358 (NCT02488759) study is in progress - it will evaluate nivolumab (and nivolumab + ipilimumab + daratumumab + BMS-986016) safety and efficacy in the treatment of HPV positive and negative HNSCC.

Currently, the KESTREL (NCT02551159) study results are being developed. The study focused on treatment with durvalumab (anti-PD-1 agent) + tremelimumab (anti-CTLA-4) vs. EXTREME chemotherapy (carboplatinum or cisplatinum + 5-fluorouracil + cetuximab).

\section{VACCINES}

Human papilloma virus viruses, mainly HPV-16 and HPV-18, are responsible for about $70 \%$ of cervical cancer diagnoses, one of most frequently occurring female cancers [25, 26]. In 2006, the first vaccinations against HPV-16 and HPV-18 appeared. Cervarix $^{\circledR}$ (GlaxoSmithKline Biologicals, Rixensart, Belgium) and Gardasil ${ }^{\circledR}$ (Merck \& Co., Whitehouse Station, NJ USA) were used. They contain virus-like particles L1 [27]. Gardasil ${ }^{\circledR}$ is a tetravalent vaccine against HPV-6, -11, -16 and 18, while Cervarix ${ }^{\circledR}$ is a bivalent vaccine against HPV-16 and 18 infections. The PATRICIA study showed a 93.2\% efficacy of the bivalent vaccine in the prevention of intraepithelial cervical neoplasia grade III (CIN III) and almost a 100\% efficacy in the prevention of occurring carcinoma in situ [27]. In the FUTURE II study $95 \%$ efficacy of tetravalent vaccine in the prevention of CIN II CIN III and carcinoma in situ was revealed [28]. Since 2014, the World Health Organisation began to recommend the vaccination of young women before first sexual intercourse, in 2 dose schemes [29]. Results of a recent performer randomized trial seem to support this recommendation [30]. The authors of the trial mention that in every group of vaccinated patients, postvaccination anti-HPV-16 and anti-HPV-18 titre were higher than titre in women infected with HPV.
Currently, there is no data to assess the efficiency of HNSCC prevention through performing vaccinations against HPV. It should be emphasized that such a prevention would be reasonable in a group of people who had never been exposed to HPV, mainly through sexual intercourse. Nevertheless, some data suggest that Gardasil ${ }^{\circledR}$ effectiveness is about $67 \%$ in $24-45$ year old women with anti-HPV antibodies present, but no virus genetic material in blood samples [31]. The need to create such studies is expressed in 95\% of HPV positive tonsil cancers and oropharynx cancers where HPV-16 and HPV-18 is detected [32].

Currently, the role of therapeutic cancer vaccines, a method of immunotherapy, is being investigated [5, 33, 34]. We are still waiting for the results from a study assessing therapeutic cancer vaccines in the treatment of HPV associated HNSCC (NCTo0019110).

\section{RADIOIMMUNOTHERAPY}

The HPV-16 is detected in 90\% of HPV positive HNSCC. Recently, a new therapeutic approach has been proposed. With radioactive marked monoclonal antibodies, viral antigens on cancer cells can be localized, providing a specific treatment. Such an approach in HPV positive HNSCC therapy has been widened and has resulted in the development of radioimmunotherapy targeted against E6 and E7 oncogenes. Radioactive marked antibodies bind to extracellular E6 and E7 resulting in providing radiation into the cancer cells region. Live cancer cells, cells which show little expression of E6 and E7 and healthy cells are induced into apoptosis as a result of such a cross-reaction.

\section{CHEMOTHERAPY}

One of the most frequently used cytostatics in HNSCC therapy is cisplatinum [35]. Studies results show that patients with HPV positive HNSCC show a greater treatment response than HPV negative HNSCC patients when treated with chemotherapy based on cisplatinum. However, such a therapy is related to many adverse events, including renal failure, dysphagia and polyneuropathy [36]. Other commonly used chemotherapeutics are 5-fluorouracil and docetaxel. In the EORTOC 24971 study, docetaxel + cisplatinum + 5-fluorouracil (TPF) vs. cisplatinum $/ 5$-fluorouracil (PF) chemotherapies were compared in the treatment of locally advanced, nonresectable, HPV positive and negative HNSCC. Progression free survival and OS were measured. Non statistically significant differences were observed between HPV positive and HPV negative HNSCC patients. They also did not gain benefits when docetaxel was added into the PF chemotherapy regimen [37].

\section{DISCUSSION}

Young, sexually active patients are predisposed to HPV infection. With the increasing rates of risky sexual intercourses, 
exposure and infection probability are getting higher and then cancer development as well. Human papilloma virus shows tropism to cervical and head and neck epithelium. The prevention method is vaccination - it reduces the high risk of cervical cancer. Because of a lack of data to assess vaccinations against HPV in the prevention of HNSCC, its role is still unsure - both in females and males. Human papilloma virus exerts an immunosuppressive effect on the immune system which favours cancerogenesis, and is simultaneously a target for immunotherapy which is highly effective in HPV positive HNSCC patients - better survival and response rates with a minimum of adverse effects is achieved. Still, new methods and targets for therapy are being sought to improve the clinical course of the disease. On the grounds of prognostic and predictive HPV infection in HNSCC, viral biomarkers in histopathological material are proposed to be detected. It seems that the coincidence of HPV infection and HNSCC is an interesting subject that demands additional studies. From a clinical point of view, knowledge of HPV status in HNSCC patient can result in better benefits because better treatment can be provided. It is highly recommended in patients with advanced disease when surgical treatment cannot be proposed and in the group of patients with recurrent and progressive disease.

\section{REFERENCES}

1. Mandal R, Șenbabaoğlu Y, Desrichard A, Havel JJ, Dalin MG, Riaz N, et al. The head and neck cancer immune landscape and its immunotherapeutic implications. JCI Insgiht 2016;1(17):e89829.

2. Kuss I, Hathaway B, Ferris RL, Gooding W, Whiteside TL. Decreased absolute counts of $\mathrm{T}$ lymphocyte subsets and their relation to disease in squamous cell carcinoma of the head and neck. Clin Cancer Res 2004;10(11):3755-62.

3. Whiteside TL. Immunobiology of head and neck cancer. Cancer Metastasis Rev 2005;24(1):95-105.

4. López-Albaitero A, Nayak JV, Ogino T, Machandia A, Gooding W, DeLeo $\mathrm{AB}$, et al. Role of antigen-processing machinery in the in vitro resistance of squamous cell carcinoma of the head and neck cells to recognition by CTL. J Immunol 2006;176(6):3402-9.

5. Gildener-Leapman N, Ferris RL, Bauman JE. Promising systemic immunotherapies in head and neck squamous cell carcinoma. Oral Oncol 2013;49(12):1089-96.

6. Payne MJ, Argyropoulou K, Lorigan P, McAleer JJ, Farrugia D, Davidson $\mathrm{N}$, et al. Phase II pilot study of intravenous high-dose interferon with or without maintenance treatment in melanoma at high risk of recurrence. J Clin Oncol 2014;32(3):185-90.

7. Downey SG, Klapper JA, Smith FO, Yang JC, Sherry RM, Royal RE, et al. Prognostic factors related to clinical response in patients with metastatic melanoma treated by CTL-associated antigen- 4 blockade. Clin Cancer Res 2007;13(22):6681-8.

8. Torre LA, Bray F, Siegel RL, Ferlay J, Lortet-Tieulent J, Jemal A. Global cancer statistics, 2012. CA Cancer J Clin 2015;65(2):87-108.

9. Pulte D, Brenner H. Changes in survival in head and neck cancers in the late 20th and early 21st century: a period analysis. Oncologist 2010;15(9):994-1001.

10. Kim L, King T, Agulnik M. Head and neck cancer: changing epidemiology and public health implications. Oncology (Williston Park) 2010;24(10):915-9.

11. Zaravinos A. An updated overview of HPV-associated head and neck carcinomas. Oncotarget 2014;5(12):3956-69.

12. Lajer $\mathrm{CB}$, von Buchwald $\mathrm{C}$. The role of human papillomavirus in head and neck cancer. APMIS 2010;118(6-7):510-9.

13. Smith EM, Ritchie JM, Summersgill KF, Klussmann JP, Lee JH, Wang D, et al. Age, sexual behavior and human papillomavirus infection in oral cavity and oropharyngeal cancers. Int J Cancer 2004;108(5):766-72.
14. IARC Working Group on the Evaluation of Carcinogenic Risks to Humans. Biological agents. Volume 100 B. A review of human carcinogens. IARC Monogr Eval Carcinog Risks Hum 2012;100(Pt B):1-441.

15. Michaud DS, Langevin SM, Eliot M, Nelson HH, Pawlita M, McClean MD, et al. High-risk HPV types and head and neck cancer. Int J Cancer 2014;135(7):1653-61.

16. Weinberger PM, Yu Z, Haffty BG, Kowalski D, Harigopal M, Brandsma J, et al. Molecular classification identifies a subset of human papillomavirusassociated oropharyngeal cancers with favorable prognosis. J Clin Oncol 2006;24(5):736-47.

17. Fakhry C, Westra WH, Li S, Cmelak A, Ridge JA, Pinto H, et al. Improved survival of patients with human papillomavirus-positive head and neck squamous cell carcinoma in a prospective clinical trial. J Natl Cancer Inst 2008;100(4):261-9.

18. Hübbers CU, Akgül B. HPV and cancer of the oral cavity. Virulence 2015;6(3):244-8.

19. Spangle JM, Munger K. The HPV16 E6 oncoprotein causes prolonged receptor protein tyrosine kinase signaling and enhances internalization of phosphorylated receptor species. PLoS Pathog 2013;9(3): e1003237.

20. Vermorken JB, Herbst RS, Leon X, Amellal N, Baselga J. Overview of the efficacy of cetuximab in recurrent and/or metastatic squamous cell carcinoma of the head and neck in patients who previously failed platinumbased therapies. Cancer 2008;112(12):2710-9.

21. RTOG. RTOG 1016 Phase III Trial of radiotherapy plus cetuximab versus chemoradiotherapy in HPV-associated oropharynx cancer. 2013.

22. Chow LQM, Haddad R, Gupta S, Mahipal A, Mehra R, Tahara M, et al. Antitumor activity of pembrolizumab in biomarker-unselected patients with recurrent and/or metastatic head and neck squamous cell carcinoma: results from the phase Ib KEYNOTE-012 expansion cohort. J Clin Oncol 2016;34(32):3838-45.

23. Ferris RL, Blumenschein G Jr, Fayette J, Guigay J, Colevas AD, Licitra L, et al. Nivolumab for recurrent squamous-cell carcinoma of the head and neck. N Engl J Med 2016; 375(19):1856-67.

24. Ferris RL, Gonçalves A, Baxi SS, Martens UM, Gauthier H, Langenberg M, et al. LBA46: An open-label, multicohort, phase 1/2 study in patients with virus-associated cancers (CheckMate 358): Safety and efficacy of neoadjuvant nivolumab in squamous cell carcinoma of the head and neck (SCCHN). Ann Oncol 2017;28 Suppl 5:605-49.

25. Li N, Franceschi S, Howell-Jones R, Snijders PJ, Clifford GM. Human papillomavirus type distribution in 30,848 invasive cervical cancers worldwide: Variation by geographical region, histological type and year of publication. Int J Cancer 2011;128(4):927-35.

26. de Sanjose S, Quint WG, Alemany L, Geraets DT, Klaustermeier JE, Lloveras $B$, et al. Human papillomavirus genotype attribution in invasive cervical cancer: a retrospective cross-sectional worldwide study. Lancet Oncol 2010;11(11):1048-56.

27. Lehtinen M, Paavonen J, Wheeler CM, Jaisamrarn U, Garland SM, Castellsagué X, et al. Overall efficacy of HPV-16/18 AS04-adjuvanted vaccine against grade 3 or greater cervical intraepithelial neoplasia: 4-year end-of-study analysis of the randomised, double-blind PATRICIA trial. Lancet Oncol 2012;13(1):89-99.

28. Villa LL, Perez G, Kjaer SK, Paavonen J, Lehtinen M, Muñoz N, et al. Quadrivalent Vaccine against Human Papillomavirus to Prevent High-Grade Cervical Lesions. N Engl J Med 2007;356:1915-27.

29. World Health Organization. Human papillomavirus vaccines: WHO position paper, May 2017. Wkly Epidemiol Rec 2017;92(19):241-68.

30. Leung TF, Liu AP, Lim FS, Thollot F, Oh HML, Lee BW, et al. Comparative immunogenicity and safety of human papillomavirus (HPV)-16/18 AS04adjuvanted vaccine and 4vHPV vaccine administered according to two- or three-dose schedules in girls aged 9-14 years: Results to month 36 from a randomized trial. Vaccine 2018;36(1):98-106.

31. Castellsagué X, Muñoz N, Pitisuttithum P, Ferris D, Monsonego J, Ault K, et al. End-of-study safety, immunogenicity, and efficacy of quadrivalent HPV (types $6,11,16,18$ ) recombinant vaccine in adult women 24-45 years of age. Br J Cancer 2011;105(1):28-37.

32. Kreimer AR, Clifford GM, Boyle P, Franceschi S. Human papillomavirus types in head and neck squamous cell carcinomas worldwide: a systematic review. Cancer Epidemiol Biomarkers Prev 2005;14(2):467-75.

33. Macedo R, Rochefort J, Guillot-Delost M, Tanaka K, Le Moignic A, Noizat C, et al. Intra-cheek immunization as a novel vaccination route for therapeutic 
vaccines of head and neck squamous cell carcinomas using plasmo viruslike particles. Oncoimmunology 2016;5(7):e1164363.

34. Morrow MP, Yan J, Sardesai NY. Human papillomavirus therapeutic vaccines: targeting viral antigens as immunotherapy for precancerous disease and cancer. Expert Rev Vaccines 2013;12(3):271-83.

35. Adams AK, Wise-Draper TM, Wells SI. Human papillomavirus induced transformation in cervical and head and neck cancers. Cancers (Basel) 2014;6(3):1793-820
36. Whang SN, Filippova M, Duerksen-Hughes P. Recent progress in therapeutic treatments and screening strategies for the prevention and treatment of HPV-associated head and neck cancer. Viruses 2015;7(9):5040-65.

37. Psyrri A, Fortpied C, Koutsodontis G, Avgeris M, Kroupis C, Goutas N, et al. Evaluation of the impact of tumor HPV status on outcome in patients with locally advanced unresectable head and neck squamous cell carcinoma (HNSCC) receiving cisplatin, 5-fluorouracil with or without docetaxel: a subset analysis of EORTC 24971 study. Ann Oncol 2017;28(9):2213-8.- 